\title{
Problems of checking personal data of jury members: Russian and foreign experience
}

\author{
Sergey Aleksandrovich Nasonov $^{1^{*}}$ and Yuliya Vladimirovna Strelkova ${ }^{2}$ \\ ${ }^{1}$ Kutafin Moscow State Law University, Moscow, Russia \\ ${ }^{2}$ Moscow Bar Association, Moscow, Russia
}

\begin{abstract}
A prerequisite of the research of issues covered by this paper is the relevance of the existing problem of collecting and checking personal data of jury members (or jury member candidates) to verify information reported by them at the stage of jury formation. The purpose of this research is to define a link between checking the personal data of jury members and the legal nature of jury proceedings and to find a balance between the need to restrict access need to ensure the legal composition of the court. To address these issues, the paper studies doctrinal approaches of Russian and foreign scientific literature, uses analysis methods, legal-technical and comparative-legal methods. This research has found that collecting and verifying personal data of jury members is typical of Russian and foreign models of proceedings in a jury court. However, a balance between the need of such research and ensuring the independence of jury members in the Russian court practice is not always observed, which is caused by gaps in legal regulation. Therefore, it seems interesting to study approaches to legal regulation of such practice in foreign models (anonymous jury and conditions of disclosing data of jury members; restricting the right to collect data of jury members in the USA after adjuration). These research results are new since they have not been described in the Russian legal periodicals and monographic literature. New research results are represented by describing problems of obtaining information of jury members by prosecution authorities, which is relevant for Russia and has never been studied before.
\end{abstract}

Keywords: jury court, jury, personal data

\section{Introduction}

The legal practice of considering criminal cases with a jury has brought attention to the problem of collecting and checking the personal data of jury members (or jury member candidates) at various stages of legal proceedings and during further stages of the criminal process. Checking personal data of jury members includes those facts that jury member candidates have reported to the court and the parties, allegedly unreliable information, at the stage of jury formation. Evaluating the relevance of information that the party tried to obtain from jury member candidates is defined by an ability of such information to be used as

\footnotetext{
${ }^{*}$ Corresponding author: sergei-nasonov@yandex.ru
} 
grounds to file a motivated objection, or be a reason for non-motivated rejection of a jury member candidate [1].

In this manner, checking personal data of jury members being a relevant guarantee of ensuring the legality of the court composition is objectively necessary and caused by the essence of jury proceedings suggesting that objective and impartial representatives of society take part in justice. However, this need collides with the issues of ensuring judicial independence of jury members determining restriction of access to personal information on jury members. Resolving this collision has a significant theoretical and practical value for court proceedings with jury members. This is a purpose of this paper whose goal will be checking two hypotheses:

1. Verifying personal data of jury members is typical of this form of court proceedings and is observed in its statutory regulation and legal practice;

2. The limits of such checks are defined by the balance of values: the need to restrict access to personal data of jury members as a guarantee of their independence and the need to ensure the legal composition of the court, which prevents reporting incorrect personal data by jury members.

\section{Methods}

To achieve these goals, it seems necessary to research doctrinal approaches developed concerning this issue in Russian and foreign scientific literature and to use analysis methods, legal-technical and comparative-legal methods by comparing regulations and legal practice of the Russian Federation and foreign countries.

The studies of scientific literature show that the problem of obtaining personal data of jury members and candidates is relevant for Russia and for the countries of the Anglo-Saxon legal system. The importance of identifying individual subjective characteristics of jury member candidates to ensure the right for fair proceeding is shared by most scientists and highlighted in some focused researches [2-4].

Since the primary way of obtaining the personal information of candidates is their polling at the stage of jury formation, most theoretical studies are dedicated to this procedure and further resolution of rejections claimed by the parties $[3,5,6]$. In some publications, the authors analyze relatively new methods of studying information of jury members.

Studying social networks helps the parties to get an insight into the candidate's personality and is actively used in practice: this is called Voir Google [7]. Advantages include the soft obtaining of necessary data based on generally-available information voluntarily posted by candidates (or jury members) [8]. The authors study the ethical aspects of online investigation and give examples of the necessity of using this method [9]. The next stage in the development of the same trend is using Big Data technologies: supporters of this method believe that it will accumulate a lot of personal information useful for qualification, which is especially relevant for the USA where the quality of preparation to jury formation can directly depend on parties' ability to pay the work of analysis and data collection experts [10].

Since the active collection of information about candidates is related to investigating their personal life, we should also note existing scientific notations on ensuring the independence and safety of jury members $[11,12]$ and issues of preserving the right of jury members and candidates for privacy. One of the most prominent discussions in this area concerns the functioning of anonymous juries in the USA, which is held by supporters of assigning anonymous juries with the ordinary position in criminal proceedings and [13] by opponents of such measures. The proposed procedure tested in some States includes the concealment of candidate names in all documents that the parties and the public has access to, and candidates are identified by numbers. However, a name of an individual jury member can be disclosed later (during case consideration and thereafter) if one of them will be able to assert the need 
of such disclosure to check the information that may result in a reversal of the sentence. Therefore, a party's appeal must not be arbitrary and shall contain some information of a suggested breach [14]. Risks generated by the activity of anonymous juries give rise to proposals on introducing a motivated model of verdict [15].

\section{Results and discussion}

Analysis of the existing Russian criminal procedural law and practice of its application results in a conclusion that the Russian model of proceedings with jury members is typical of collection and verification of their personalities. Depending on the subject and procedural form of such verification, it can be differentiated into judicial (criminal procedural) and nonprocedural (undertaken by the parties). In its turn, the judicial (procedural) check can be differentiated into a check of information given in the first-instance court and the same during appeal proceedings.

Judicial check of personal data of jury members in the first-instance court is done as a survey of jury members, requesting records and other documents from various authorities by the court. It should be noted that statutory regulation of these surveys is envisaged only for taking such actions towards jury member candidates during the formation of the jury. Provisions of Parts 3,8, Article 328 Criminal Procedural Code of the Russian Federation regulates such surveys undertaken by the presiding judge and the parties. The law sets out a sequence of participation of the parties in this survey, framework requirements to the form of questions used by the parties in this procedural action [16-18].

Applicable law does not provide any regulation of this survey of jury members by the presiding judge and the parties at the stages of proceedings following the jury formation. The legal practice uses a procedural survey at the stage of jury formation in a similar fashion. It appears that such a survey should be initially undertaken by the presiding judge and only then the parties are provided with an opportunity to ask questions to the surveyed person. Applicable law does not provide any indications as to what legal provisions must be explained to the surveyed presiding judge, whether it is entitled to answer questions asked, what the limits of intervening into enigma private life are, etc. The procedure of legal check of personal data of jury members must be properly regulated in the criminal procedural law.

Judicial check of personal data of jury members undertaken by the court of appeal has even more gaps than the above procedure. The court of appeal is entitled, on the application, to demand any information related to the personality of jury members if the question is about a material breach of the criminal procedural law in the form of reporting incorrect personal information by the jury member candidate at the stage of jury formation. Along with that, the Criminal Procedural Code of the Russian Federation contains no provisions giving rise to assert that such a check can be done by the court of appeal at its own initiative (for example, if this argument is present in the appeal). It seems that this drawback of the law that must be eliminated by modifying Article 389.13 of the Criminal Procedural Code of the Russian Federation. It appears that applicable law must expand the capabilities of the court of appeal in checking the personal data of jury members, namely in providing an opportunity to survey members concerning the above circumstances.

Non-procedural checks of personal data of jury members undertaken by the parties can be done at various stages of legal proceedings and various stages of the process or between them. This check may suggest reviewing open (publicly available) data, for example, those posted in social networks, and analysis of information from secure sources - previous convictions and committed offenses. Open data can be used by both parties [19].

Another unequal situation is typical of processing personal data from secure sources. The Russian law suggests access of the prosecutor to a wide range of personal data enlisted in the departmental regulations [20]. The law contains no mechanisms of legal control over the 
prosecutor's checking activity. It seems that the procedure of retrieving data on jury members and their relatives must suggest a number of confidentiality guarantees related to undertaking judge functions by them.

The problem of excessive powers of the prosecution office is also typical of the USA proceedings [21], and in some States, personal data can be reviewed before juration, and the defense team can present a petition to the court on the check of respective candidates. After issuing a verdict, any check is possible only after receiving special permission from the court, and the party demanding such permission must substantiate its petition [22].

\section{Conclusion}

Verifying personal data of jury member is typical of Russian and foreign models of proceedings in a jury court. However, a balance between the need of such research and ensuring the independence of jury members in the Russian court practice is not always observed, which is caused by gaps in legal regulation. In this connection, it seems interesting to consider approaches to statutory regulation of such verification in foreign models.

\section{References}

1. Kassatsionnoe opredelenie SK UD VS RF ot 26.07.2012 g. [Cassational ruling of the Judicial Division for Criminal Cases of the Supreme Court of the RF dated 26.07.2012 No. 47-012-30sp-a. Accessed on: March 17, 2021. [Online]. Available: https://www.consultant.ru/

2. R. Rogers, A. Sharf, B. Myers, E. Drogin, M. Williams, Beh. Sc. \& the Law 38, 12-31 (2020) https://doi.org 10.1002/bsl.2451

3. T.W. Frampton, Mich. L. Rev. 118, 785-840 (2020) https://doi.org/10.36644/mlr.118.5.cause

4. C.C. Kates, St. Louis Univ. Pub. Law Rev. 35(2), 415-442 (2016)

5. S.A. Nasonov, Relevant Iss. Rus. Law. 12, 2841-2846 (2014)

6. T.A. Vladykina, J. Rus. Law 5, 84-94 (2014)

7. C.M. Morrison, L. Rev. 35, 285-303 (2014)

8. L.A. Harle, St. Mary's L.J. 49, 665-698 (2018)

9. B.A. Fortuno, J. Advoc. \& L. 70, 3-20 (2019)

10. A.G. Ferguson, L. Rev. 91, 935-1006 (2016)

11. E.G. Kotelya, Rus. Legal J. 3, 96-100 (2008)

12. I.N. Krapchatova, Bul. Udmurt Univ. Ser. Ec. and Law 3, 210-213 (2013)

13. N.J. King, Vanderbilt Law Rev. 49, 123-159 (1996)

14. C. Keleher, Univ. San Francisco Law Rev. 44(3), 531-570 (2010)

15. L. Mangat, Cornell L. Rev. 103, 1621-1649 (2018)

16. Punkt 13 Postanovleniya Plenuma VS RF ot 22.11.2005 № 23 [Declaration of the Russian Federation Plenum of Supreme Court, Item 13, dated 22.11.2005 No. 23] Accessed on: March 17, 2021. [Online]. Available: https://www.supcourt.ru/documents/own/?category=resolutions_plenum_supreme_cou rt_russian\&year=2005

17. Apellyatsionnoe opredelenie SK UD VS RF ot 14.06.2013 g. № 51-APU13-10SP [Appellate decision of the Judicial Division for Criminal Cases of the Supreme Court of the Russian Federation dated 14.06.2013 No. 51-APU13-10SP]. Accessed on: March 17, 2021. [Online]. Available: https://www.consultant.ru/

18. Apellyatsionnoe opredelenie SK UD VS RF ot 23.05.2013 g. № 44-APU13-4SP [Appellate decision of the Judicial Division for Criminal Cases of the Supreme Court 
of the Russian Federation dated 23.05.2013 No.44-APU13-4SP]. Accessed on: March 17, 2021. [Online]. Available: https://www.consultant.ru/

19. Apellyatsionnoe opredelenie Sudebnoi kollegii po ugolovnym delam Verkhovnogo Suda RF ot 27 noyabrya 2018 g. № 49-APU18-17sp [Appellate decision of the Judicial Division for Criminal Cases of the Supreme Court of the Russian Federation dated November 27, 2018 No. 44-APU18-17sp]. Accessed on: March 17, 2021. [Online]. Available: https://www.consultant.ru/

20. Prikaz Genprokuratury Rossii ot 22.11.2013 № 506 “Ob utverzhdenii i vvedenii v deistvie Instruktsii o poryadke obrabotki v organakh prokuratury Rossiiskoi Federatsii personal'nykh dannykh, poluchennykh v svyazi s osushchestvleniem prokurorskogo nadzora" [Order of the General Prosecutor's Office of Russia No. 22.11.2013 No. 506 On Approval and Enacting the Instructions for Processing Personal Data Obtained in Relation With prosecutor's supervision in Prosecution Authorities of the Russian Federation]. Accessed on: March 17, 2021. [Online]. Available: https://www.consultant.ru/

21. V.B. Johnson, Yale L. \& Poly Rev. 34, 387-424 (2016)

22. Commonwealth vs. Lord Hampton. 457 Mass. 152 (2010) Accessed on: March 17, 2021. [Online]. Available: https://caselaw.findlaw.com/ma-supreme-judicialcourt/1529796.html 